\title{
Poverty and Agricultural Productivity Growth Nexus in the Non-Plantation Agriculture in Sri Lanka
}

\author{
H.M.W.A. Herath \\ Department of Economics and Statistics, University of Peradeniya, Sri Lanka \\ ariyarathneherath@gmail.com
}

\begin{abstract}
Not only there is a close relationship between poverty and agriculture productivity but also agriculture is considered as a significant means of plummeting poverty in the long-term and in the shortterm. While agriculture may not be central as the driver of economic growth in current global neo-liberal economic context it is generally accepted that the food security and livelihood development aspects for all still warrants developing agriculture, a situation that holds true for Sri Lanka too. Productivity in agriculture is determined by conditions in both the natural, socioeconomic and community factors. The productivity in the country's agriculture sector is rooted in the farming system, namely, the farm and the farmer/farm operator. These two units are in an interacting whole which makes property of one a quality of another. Small plot size, the existing tenure system, low levels of education and skills of farm operators and behavior of two patrons (government and traders) in the sector are the major backward determinants affecting to place in the farmer into a vicious cycle of poverty. This background does not help to generate a dynamic, risk bearing and enterprising farmers for the economy and this leads to low productivity and then the continuation of poverty of farmers. The lack of attentiveness of overall situation and lack of holistic approach to problems providing appropriate solutions to individuals are constraints in agriculture development. Solution is the hallmark of policies and interventions in agriculture. Present focus is also on subsistence-based model and the approach is piecemeal.
\end{abstract}

Keywords: Farmer, Farm, Agriculture, Social Factors, Productivity

\section{Introduction}

Though the contribution of agriculture value added to the Gross Domestic Product (GDP)of the country is declining (which stood at 46.3 per cent in 1950 and 19.4 per cent in 2000 to 6.9 per cent in 2017) while the contribution of industry and services sectors increased over the same period, its role in the economy has not declined. The significant role of agriculture in the economy in spite of its diminishing contribution to economy is confirmed by the size of the agriculture lab our force which stood at 26.1 per cent in 2017(CBSL, 2017), almost thrice its share in the GDP. This heavy dependence of population on agriculture for living has important socio-economic consequences, especially in the politically sensitive areas of income poverty and food security. While agriculture may not be central as the driver of economic growth and development in current context, it is generally accepted that the food security and livelihood development aspects for all still warrants developing agriculture. This situation that holds true for Sri Lanka as well. Not only there is a close relationship between poverty and agriculture productivity but also agriculture is considered as a significant means of plunging poverty both in the long-term and in the short-term. It is claimed that historically, poverty reduction has been very closely related to agriculture, particularly to the rate of growth of agricultural productivity. In other words, it means that the countries that have increased their agricultural productivity have also achieved economic growth and the greatest reductions in poverty (DFID, 2004).

The affiliation between agriculture and livelihood development process is seen by development dialogue at present in relation to four major areas, namely, as impact on income generation (direct and immediate), cheaper food contributing to better food security, contributing to growth and generation of economic activity in other sectors and, stimulating and sustaining economic transition in an economy (DFID, 2004). Therefore, as a tropical agricultural society in nature, it is worthwhile to understand the importance and impact of nonplantation agriculture on poverty reduction in Sri Lanka and the socioeconomic factors affecting productivity in Sri Lanka's agriculture by focusing on the farm and the farmer. In addition, it is important to recognize the results, strengths and weaknesses of recent policy intervention process in agriculture sector under the neoliberal economic policy frame. This paper is divided into five sections. The first section is an introduction to the study including the objectives of the study. The second section provides a review of literature and the third section describes the analytical procedures. The fourth section is results and discussion which provides a description of the agriculture sector of Sri Lanka with a focus on its contribution to the economy and the 
socio-economic situation of the people. This section also includes an assessment of the relationship between poverty and agriculture. Further, it analyzes the patterns of productivity in the agriculture sector of the country with reference to some key food crops in the non-plantation agriculture sector, and socioeconomic factors affecting productivity in relation to farm organization and farmers. The final section is the conclusions.

Objectives of the Study: Investigate the poverty and agriculture productivity nexus focusing on farm and the farmer. Examine the socioeconomic and community factors affecting productivity in Sri Lanka's nonplantation agriculture by focusing on the farm and the farmer.

\section{Literature Review}

In Sri Lanka, researchers point to stagnation and decline in the earnings and productivity in the agricultural sector during the past three decades and cite, in addition to adverse weather conditions, policy, market, attitudinal (social) and technology-related causes for this situation (Abeysekera, 2008). Although the early policy priorities with regard to agriculture altered later on with export agriculture receiving the support of the government in the 1980s the concentration was on increasing output, but not by enhancing productivity and producer earnings except in the case of introduction of new improved varieties (Gunawardana, \& Somaratne, 2000). Increasing the cropland area by establishing new settlement schemes and rehabilitating old ones, crop diversification etc. were part of this new output centred strategies adopted by the government for the sector. However, an increase in agriculture production and productivity is not only a problem of quantity production but also a problem of total factor productivity. Poverty agriculture nexus can be elaborated with reference to another feature of agriculture productivity known as agricultural productivity gap. In all less developed countries agriculture's share of employment is higher than its share of the GDP which is also a feature of Sri Lanka's agriculture.

According to existing to studies, agricultural productivity gap is around a factor of four in developing countries, on average (Adamopoulos, \& Restuccia, 2014; Gollin, Lagakos, \& Waugh, 2012; Lagakos, \& Waugh, 2013). This means that value added per worker is higher in the non-agriculture sector than in agriculture which results in drawing workers out of agriculture creating lab our shortages and also high lab our costs. This adversely affects the agriculture sector livelihood and income by subsidizing non-plantation agriculture in countries like Sri Lanka allowing it to be sustained at non-viable levels (World-Bank, 2009). It is also seen that certain types of off-farm employment opportunities that are considered as having better social status (Jayasena, 1998) and they by providing regular work and stable income attract the better educated and enterprising youth out of agriculture affecting its productivity even further. Agriculture also provides a ready solution to the problem of food security in poor households thus help alleviate poverty in the short-term. In the long-term agriculture help drive economic growth forward (Lewis, 1954) ${ }^{1}$ through the long-term poverty reduction and livelihood development. Agriculture productivity therefore has been identified by many analysts as the single most important factor of achieving economic growth, employment creation and poverty reduction as well as a solution to food security issues.

Though the link between poverty reduction and growth in agriculture may be challenged by analysts of the Sri Lanka situation who would claim that Sri Lanka has, in spite of slow growth in agricultural productivity has achieved good results in poverty reduction, it cannot be denied that the long-term solutions to poverty is in economic growth and historically agriculture has played a very important role in overall economic growth and development (World-Bank, 2002). Agriculture driven growth and development model of classical economics today have gone out of fashion and the new debate questions the earlier views on economic development, particularly those on the link between agriculture and economic development (Hayami, \& Ruttan, 1985; Mellor, 1986; Schultz, 1964). Further, economists no longer accept that economic development invariably ends poverty and most importantly poverty reduction has to wait till economic development is achieved. The literature reviewed above shows that there is a very strong relationship between poverty

${ }^{1}$ All cases of economic development from $18^{\text {th }}$ and $19^{\text {th }}$ century Europe and North America to late $20^{\text {th }}$ century East Asia have been associated with agricultural development. However, the poorest economies today have failed to achieve agriculture driven take off to industrialization. 
reduction or livelihood development of low-income categories and agriculture productivity improvement. Historically it was proved that initial stages of the development process in many developed countries, agriculture assisted in different ways for the development of other sectors such as industrial and manufacturing.

\section{Methodology}

The major data collection tools for this study were secondary sources and obtaining data from Focus Group Discussions (FGDs). Agricultural farmers from villages in the nine provinces of the country were selected purposely to the FGDs. Altogether nine FGDs were conducted and which was conducted based on the land extent, quantity produced and a number of active farmers in each province. Accordingly, we have organized FGDs as one in each province for Central Province, North Central Province, Northern Province, Eastern Province, Uwe Province, North Western province, and Southern Province with paddy and vegetable farmers. Further, one in Sabaragamuwa Province and one in Western Province with vegetable farmers were also conducted. All FGDs were conducted in informal settings, often in a residence of a household. This method was used in obtaining both farm and farm operator (farmers) data and information for the analysis of farmer's perception regarding issues related to productivity, socioeconomic issues, strengths and weaknesses of existing systems and practices in the regions. Around 50 individuals were presented in all of the FGDs. Secondary sources such as reports of Department of Census and Statistics (DCS), Central Bank of Sri Lanka (CBSL), The World Bank, Asian Development Bank, and Department of Agriculture etc. were utilized where necessary.

Productivity is the efficiency in converting inputs or a combination of inputs into the output and is defined as a ratio between output volume and input volume. Productivity is measured by an indicator which is a fraction, the numerator of which is a measure of output and the denominator is a measure of input indicator (Szabo, 2003). Productivity indexes measure changes in the efficiency with which inputs are transformed into outputs (Adamopoulos, \& Restuccia, 2014). Agricultural productivity is a reference to overall efficiency of production and has been defined by several scholars with reference to their own views and disciplines (Dharmasiri, 2010). Yield per unit (lab our and land) is a popular indicator for its ease of calculation. In this study we take the yield per unit of land and value of yield per unit of lab our as indicators of productivity considering the importance of land and lab our in determining productivity and also for data availability. Paddy farming in Sri Lanka receives special reference as the biggest player in terms of its share in the GDP, food security and the families involved.

According to the Department of Agriculture there are around 1.8 million families in the paddy sector cultivating around 870,000 hectares of paddy annually ${ }^{2}$. Productivity however is not determined by inputs alone. There are other external factors in different countries and different societies. The efficiency of converting inputs into output is intervened by these external factors in more or less. In agriculture, these external factors can be categorized into three broad sets as follows; The factors in the natural world such as weather, soil condition and climate. The factors in the social, psychological and community world such as relationships, behavior, attitudes and beliefs. The factors in other socioeconomic and structural such as income poverty, level of education, availability of extension services and inputs. The efficiency which decides the rate of conversion is both socioeconomic, political and behavioral factors related. This is because neither technology nor any other input becomes part of the production process without decisions of people involved whose decisions are influenced by the social contest. Better seed and crop varieties, pesticide or fertilizer can improve productivity only if farmers decide to use them.

In other words, inputs are the necessary but not sufficient conditions of productivity and efficiency. Establishing causal relationships between socioeconomic determinants is not an easy task as socioeconomic phenomena are vague and inconsistent by nature. Therefore, in this analysis the attempt is not to seek for causal connections but to identify possible influences in broad contexts in which multiple determinants are in operation interacting with each other. Socioeconomic factors are treated not as determinants but as

${ }^{2}$ Information given in the website of the Department of Agriculture.

http://www.agridept.gov.lk/index.php/en/crop-recommendations/808, Accessed on September 23, 2014 
contributors to the output and outcome. In the analysis we examine the role of socioeconomic, community and psychological determinants in productivity focusing on the two main elements in the farming system, namely, the farm and the farmer. In what follows therefore we shall examine the socioeconomic background of the farm organization and related operations and the socioeconomic nature of the farmer and the impact of these two on productivity.

\section{Results and Discussion}

Agriculture Sector in Sri Lanka: Though the share of agriculture in the GDP has been falling at a steady rate the majority of the population of Sri Lanka still lives in rural areas with little change over the last several decades and agriculture is the mainstay of the rural economy. At present the contribution of Sri Lanka's agricultural sector in the GDP is the lowest in the South Asian region ${ }^{3}$ and is comparable to that of the middleincome countries in South East Asia. In terms of the size of the agricultural labor force as against size of the sector in the economy Sri Lanka is closer to South East Asian countries than to those of South Asian countries (Table 1). The share of agriculture in the GDP in 2017 was 6.9 per cent and agricultural lab our force in the country was 26.1 per cent in 2017 (CBSL, 2017).

Table 1: The Share of Agriculture in the GDP and the Agriculture Labor Force in some Selected Counties in South and South East Asia 2012.

\begin{tabular}{lll}
\hline Country & Share in GDP & Labor Force \\
\hline Thailand & 11.4 & 38.9 \\
Philippines & 12.7 & 32.1 \\
Malaysia & 12.0 & 12.6 \\
Indonesia & 14.7 & 35.1 \\
Pakistan & 26.0 & 45.3 \\
Nepal & 36.8 & n.a \\
India & 17.5 & $48 / 9$ \\
Bhutan & 16.5 & 62.2 \\
Bangladesh & 18.3 & 47.5 \\
Afghanistan & 27.3 & n.a \\
Sri Lanka & 11.0 & 31.0 \\
\hline
\end{tabular}

Source: Economic and Social Statistics of Sri Lanka 2014, Central Bank of Sri Lanka

In the non-plantation agriculture sector food crops dominate with paddy cultivation making the biggest contribution to the GDP. Its share is only 10 percentage points below the combined contribution of three plantation crops (Table 2). The combined contribution of all food crops (paddy and other food crops) is only little less than two third of the agricultural GDP however if one takes other food crops of which a significant portion is consumed domestically as food the food production in the agriculture sector moves above two thirds of the GDP.

Table 2: Share of Agricultural GDP in 2012 (Excluding Forestry and Livestock).

\begin{tabular}{lll}
\hline Crop & Product Volume (000) & Percent \\
\hline Tea, Rubber and Coconut & 66,704 & 27.2 \\
Paddy & 43,596 & 17.8 \\
Minor Export Crops & 11,507 & 4.7 \\
Other Food Crops & 111,722 & 45.6 \\
Other Agricultural Crops & 11,535 & 4.7 \\
Total & 245,064 & 100.00 \\
\hline
\end{tabular}

Source: Economic and Social Statistics of Sri Lanka 2014, Central Bank of Sri Lanka

\footnotetext{
${ }^{3}$ Maldives is not considered as its land does not support regular agriculture and crop production.
} 
Non-plantation agriculture in Sri Lanka is divided into three climatic zones which are the wet zone, the intermediate zone and the dry zone which consists of over $75 \%$ of the land area support food crops through widespread irrigation facilities. In terms of production the agriculture of Sri Lanka is divided into two major sectors as domestic traditional (food crops mainly) agriculture and plantation (commercial export crops) agriculture. Domestic traditional agriculture with the aim of producing food for consumption has a history of more than 2000 years while the commercial crops except the coconut were introduced to the country by the British colonial administration. Coconut though is considered plantation crop has been in the domestic agriculture for centuries. With the establishment of dry zone colonies/settlement schemes a new component primarily aimed at paddy production was added to the agriculture sector of the country. In addition, shifting cultivation called Chena cultivation also plays a role in the country's agriculture as a subsistence level food producer in the dry zone. Chena cultivation is practiced by farmers on mainly encroached crown land.

Table 3: Extent of Land under Different Crop Varieties2012

\begin{tabular}{lll}
\hline Crop Variety/Land Use Type & Extent Cultivated (Ha) & Percentage \\
\hline Paddy & 977,561 & 46.22 \\
Vegetable and tubers & 85,663 & 4.0 \\
Fruits & 85,066 & 4.1 \\
Other Field Crops & 130,297 & 6.1 \\
Plantation Crops & 716,320 & 33.9 \\
Minor Export Crops & 119,862 & 5.7 \\
Total Extent & $2,114,739$ & 100.0 \\
\hline
\end{tabular}

Source: The Department of Agriculture and Central Bank of Sri Lanka Various Reports

Apart from the plantation agriculture which produces mainly for export (except for coconut) the other major player in the country's agriculture in terms of both the extent cultivated and volume produced is paddy. Other agricultural produce are the vegetables and fruits and a number of crops known generally as field crops and seasonal crops. The land area covered by the different crops is given in Table 3. Of the agriculture produce except for the plantation agriculture, the produce from other sources is used mainly for domestic consumption. Except for the small quantities that exported on unscheduled basis almost all of the paddy production is consumed locally and so is the consumption of fruits and vegetables. A part of the Minor Export Crops is also used by the local consumers. For instance, in 2012 of the total production of 25,637 MT of pepper and 16,087 MT of cinnamon the country exported only 14, $637 \mathrm{MT}$ and 10,532 respectively. For the same year of the total production of 555 MT of cardamom only 10MT, which is only 2 per cent of the production was exported the same year (CBSL, 2013). Therefore, agricultural sector is not only important for Sri Lanka as a food producer. Though the exports from Sri Lanka have shifted to industrial products in the recent years agricultural produce still make a significant contribution to the country's export earnings (Table 4).

Table 4: Agricultural Exports Earnings, Sri Lanka (Rs. Bn.)

\begin{tabular}{llllllllll}
\hline \multicolumn{1}{c}{ Product } & $\mathbf{2 0 0 4}$ & $\mathbf{2 0 0 5}$ & $\mathbf{2 0 0 9}$ & $\mathbf{2 0 1 0}$ & $\mathbf{2 0 1 1}$ & $\mathbf{2 0 1 2}$ & $\mathbf{2 0 1 3}$ & $\mathbf{2 0 1 4}$ & $\mathbf{2 0 1 5}$ \\
\hline Tea & 74.9 & 81.5 & 136.2 & 162.8 & 164.9 & 180.4 & 199.5 & 212.6 & 182.0 \\
Rubber & 5.2 & 4.7 & 11.3 & 19.6 & 22.8 & 15.7 & 9.2 & 5.9 & 3.6 \\
Coconut & 11.5 & 11.4 & 18.6 & 18.7 & 29.4 & 26.6 & 11.1 & 28.0 & 30.1 \\
Other Agri. Crops & 16.4 & 18.4 & 43.9 & 59.5 & 62.4 & 76.0 & - & - & - \\
Total Agri. exports & 108.0 & 116.0 & 210.1 & 260.6 & 279.5 & 297.7 & - & - & - \\
\hline
\end{tabular}

Source: Annual Reports, Various Years, Central Bank of Sri Lanka and Sri Lanka Custom.

As the above Table 4 shows the export earnings from agricultural produce have increased by nearly three times during the past 8 years with some products displaying even bigger increases. What is noteworthy in this context is the near five times increase in the export earnings of other agricultural crops indicating that not only agricultural exports are solid performers but also export of non-traditional (non-plantation) agricultural crops is establishing itself as a valuable player in the economy. 
Poverty Agriculture Nexus in Sri Lanka: Not only there is a close association between poverty and agriculture based livelihood but also agriculture is considered as an important means of both reducing poverty in the long-term and alleviating it in the short-term. It is claimed that historically, rates of poverty reduction have been very closely related to agricultural performance - particularly to the rate of growth of agricultural productivity. This in other words means that the countries that have increased their agricultural productivity have also achieved economic development and the greatest reductions in poverty (DFID, 2004). The relationship between agriculture and poverty reduction is seen by development discourse today in relation to four areas, namely, as impact on income which is direct and immediate, cheaper food contributing to better food security, contributing to growth and generation of economic activity in the non-farm sector and finally inspiring and sustaining economic transition (DFID, 2004). The FGDs conducted in nine provinces specially the provinces in the Dry Zone of Sri Lanka revealed that if farmers had better harvest it was affected to enhanced their income and contributed to resolve the issue of food security.

These findings are consistent with the findings of (Xavier, Lin, Thirtle, \& Wiggins, 2001), who claim that growth of agriculture reduced poverty through the creation of jobs on the land, linkages from farming to the rest of the rural economy, and a decline in the real cost of food for the whole economy. Sri Lanka's total population of 21.4 million the rural population is around $80 \%$ and the majority of it is engaged in agriculture as indicated by the large labor force (26.1\%) engaged in agriculture (CBSL, 2017). The total agriculture holdings are 1,783,473 of which 1,387, 521 are used for crops only agriculture (DCS, 2012). This indicates to a dependence on crop production on small land holdings and also dependence of a large segment of the rural population on agriculture. The average income of those who are engaged in agriculture is below that of workers in industry and service sectors (HIES, 2012/13). Average income of rural households is $2 / 3$ of urban households (HIES, 2012/13). The poverty head count though has gone down between 1990/91 and 2009/10 overall the poverty level in the rural sector is still almost twice that in the urban sector, i.e. 5.3\% and $9.2 \%$ (CBSL, 2013). Gini coefficient for household income was for rural sector and urban sectors were 47 and 51 respectively showing a marginally better income distribution in the rural sector.

This however is more an indicator of poverty rather than income equality. Further, rural household income distribution and poverty rates by sector for the country show poverty rate for agriculture sector to be $24.1 \%$ while the same for non-agriculture sector to be $16.4 \%$ with Sabaragamuwa, and Uva recording rates over $30 \%$ (World-Bank, 2012). Add these income differentials and poverty levels are the food security issues that are directly linked to poor levels of production and productivity in the agriculture sector. This dependence of a large population on agriculture, the levels of poverty among them and the socio-economic and also political consequences of this dependency naturally makes governments to pay attention to agriculture even if their policy focus is industry and service lead growth. Agriculture production affects not only income levels and through that poverty, but also food security. Declining food production in turn affects household consumption and supply of food resulting in food insecurity.

Food security is a major concern for the household of the agriculture sector in Sri Lanka with impact on aggravating the problems of poverty. A World Food Program report for April 2014 says that in Sri Lanka the three consecutive years of draught has resulted, among other things, in increased food insecurity doubling the numbers to 768,000 (World-Food-Programme, 2014). The conclusion one can draw from these is that the agricultural production needs improvement to address the problem of poverty in the agriculture sector. With heavy pressure on land suitable for agriculture in the country improvements in the production in the agriculture sector can be made only by increasing productivity. Discussions with farmers showed that during the dry seasons they are facing numerous difficulties and as a result, depend on either government subsidy or credit from money lenders in the informal money market.

The agricultural sector is the principal source of livelihood directly and indirectly to a vast majority of the population in all developing countries, especially those who live in rural areas. Both in low income countries and in many middle income countries (especially those who have achieved middle income status recently) agriculture provides livelihood for over $1 / 3$ of their population (see Table 1). Incidentally these also are the regions where poverty is more pronounced. In Sri Lanka dependence of a large population on agriculture has largely remained unchanged in the recent years even though the share of agriculture in the GDP has been going down at a steady pace (Table 5). However, the plus side of this development in Sri Lanka is that despite 
the declining share of agriculture in the GDP the value of agriculture has gone up again at a reasonable pace (Table 5).

Table 5: Share of GDP, Production Volume and Labor Force in Agriculture

\begin{tabular}{llllll}
\hline Category/Year & $\mathbf{2 0 0 9}$ & $\mathbf{2 0 1 0}$ & $\mathbf{2 0 1 1}$ & $\mathbf{2 0 1 2}$ & $\mathbf{2 0 1 7}$ \\
\hline GDP share (\%) & 12.0 & 11.9 & 11.2 & 11.1 & 6.9 \\
Volume (Rs.000) & 613,694 & 717,710 & 791761 & 833,477 & - \\
Labor Force (\%) & 32.6 & 32.7 & 33.0 & 31.0 & 26.1 \\
\hline
\end{tabular}

Source: Economic and Social Statistics of Sri Lanka 2014 and2017, Central Bank of Sri Lanka

As the Table 4 shows the value of agriculture production is on an upward movement and there is around $1 / 3$ increase in the volume during the three-year period between 2009 and 2012. Add to that the labor force in the agriculture sector has remained almost the same up to 2012 but it was declined to $26.1 \mathrm{in} 2017$. This is an indication, though it does not establish a very conclusive trend, that there is improvement in the living standards in the agriculture sector meaning that the poverty situation in the agriculture sector has been changing for the better. Yet it is too early to conclude that the sector has been successful in providing a solution to poverty.

Pattern of Productivity in the Agriculture Sector: Non-availability of a comprehensive and dedicated dataset is a major constraint in understanding the issues of productivity in the agricultural sector of the country. The yield per unit of land ${ }^{4}$ for some selected groups of crops, namely, plantation crops, paddy, minor exports crops, some field crops and some vegetable and labor productivity in between sectors is very important measures to evaluate the productivity of agriculture sector. Figure 1 shows that labor productivity in non-plantation agriculture sector is considerably low compare with other sectors in Sri Lanka in year 2014. This low productivity is the major determinant for getting rural farmers in to poverty and indebtedness. Labor productivity ${ }^{5}$, as measured by GDP (in 2002 prices) per hour worked, increased by 6.1 per cent to Rs. 192.55 per hour in 2014 compared to Rs. 181.51 per hour in 2013. In 2016, it was increased up to 467.23 and little deceased in 2017 with Rs. per hour of 458.29 (CBSL, 2014, 2017). This increase was achieved across all three sectors in the economy. The highest labor productivity growth of 8.7 per cent was observed in the industry sector. The agriculture sector recorded a 4.3 per cent growth in productivity, while the service sector recorded a relatively low productivity growth of 3.4 per cent during the period 2013-14. However, it was increased more than 100 per cent during the period 2014-2016 in all three sectors (Table 6).

Table 6: Labor Productivity by Major Economic Sectors

\begin{tabular}{lrrll}
\hline Item & $\mathbf{2 0 1 3}$ & $\mathbf{2 0 1 4}$ & $\mathbf{2 0 1 6}(\mathbf{a})$ & $\mathbf{2 0 1 7 ( Q 1 - Q 3 ) ~ ( a ) ~}$ \\
\hline GDP at Constant (2002) Prices, Rs. Mn & $3,266,041$ & $3,506,664$ & $8,167,563$ & $6,206,968$ \\
$\quad$ Agriculture & 352,583 & 353,709 & 644,262 & 461,010 \\
$\quad$ Industry & $1,016,886$ & $1,132,892$ & $2,399,285$ & $1,862,046$ \\
$\quad$ Services & $1,896,572$ & $2,019,973$ & $5,124,016$ & $3,883,912$ \\
$\quad$ & & & \\
$\quad$ Labor Productivity, Rs. Per hour worked & 181.51 & 192.55 & 467.23 & 458.29 \\
$\quad$ Agriculture & & & & \\
$\quad$ Industry & 79.97 & 83.33 & 172.28 & 165.77 \\
$\quad$ Services & 214.70 & 233.28 & 504.55 & 479.42 \\
& 214.42 & 221.71 & 570.23 & 564.62 \\
\hline
\end{tabular}

GDP at Constant (2010) Prices, Rs. Mn.

Source: Department of Census and Statistics, 2017; Central Bank of Sri Lanka, Annual Report 2014

\footnotetext{
${ }^{4}$ In developed countries the standard measurement productivity in the agriculture sector is Total Factor Productivity Index (Szabo, 2003). In Sri Lanka there however have been attempts by individual researchers to develop suitable indexes to measure agriculture productivity (Dharmasiri, 2010).

${ }^{5}$ Labor productivity was calculated using the total employment as the input measure and GDP as the output measure until 2013. In line with international guidelines the total number of hours worked is used as the measure of labor input since 2014.
} 
Despite the fact that, the agriculture sector recorded a reasonable labor productivity growth, the level of labor productivity in the sector is the lowest, when compare with other sectors. Output per hour worked in the agriculture sector is less than half the value recorded by other two sectors, signaling that this sector needs further attention in terms of improving productivity. This is further important, as approximately 26 per cent of workers in the country are employed in the sector, contributing only to 7 per cent of the total output of the country, thereby leading to imbalances in terms of income distribution and inclusiveness of growth. It is also evident that workers in the agriculture sector are left with more idle work hours than those in the other two sectors. By the discussions with farmers it was found that this trend can be prominently observed during periods of crop damage due to adverse weather conditions. Initiatives should be taken to utilize such idle work hours to uplift the livelihoods of people who are engaged in the agriculture sector in order to improve the national output.

Promoting disease and weather resistant crop varieties and improved planting methods would further enhance productivity in the agriculture sector. Workers in the agriculture sector should be trained in skills that enable them to engage in employment in other sectors during idle periods. Group discussion with farmers highlighted that lack of extension services adversely affected to reduce production and productivity of resources used in farming. Though Sri Lanka's crop yields are poor and productivity growth is slow even by Asian standards they are not the only features of agricultural productivity of the country. An examination of the performance of individual crops and yields show that improvements are few and far between and that yields are highly volatile. In addition, there are significant yearly variations in yields within individual crops and also regional variations in yields. The yield data for selected years for selected field crops and yield data by year and producing region for paddy, big onion, potato and seasonal crops demonstrate the above variations and volatility.

They also show that except for a few crop varieties yield levels of others are stagnating (e.g. onion) and the yields of some varieties are even showing a downward movement (e.g. gingelli and black gram). Yearly fluctuations in yields are a common feature of all crops varieties while regional variation is widespread in paddy yields (Figure 3). There are some regional variations in yield of onion grown in Polonnaruwa District displaying lower yield compared to the yield in the other districts and also potatoes grown outside the upcountry recording lower yield. All these point to an unclear state with regard to productivity in the agriculture sector. Above yearly fluctuations of yields in individual crops can be accounted for by weather conditions to large extent. Paddy yields are highly sensitive to draughts and rains/floods ${ }^{6}$ and so are many field crops that are cultivated during the Yala season. The lack of clear productivity increase needs explanation outside of forces of nature. This is where socioeconomic and community factors are relevant to understand the situation. Agriculture productivity is the indicator of conversion efficiency of inputs and therefore is an indicator of the performance of the sector.

In agriculture more than in many other production contexts several factors intervene in the process. These external factors include the conditions and forces of both the physical determinants and the socioeconomic determinants within which agricultural operations take place. On the part of the natural world there are variable and uncertain forces such as weather (rains, floods and draughts for example) and more static conditions such as ecology and environment (climate, soil etc.). On the part of the socioeconomic and community world there is a whole host of socioeconomic, cultural relations and the behavior and attitudes of different operators of which farmer is the main component. It is common among risk analysts in agriculture to view agricultural production as having sandwiched between natural risks, pertaining to natural world and social risks that are part of the social system and structure. Any attempt to understand the social and economic factors influencing agricultural production therefore should approach the problem of productivity from the direction of the socioeconomic systemic conditions. Socioeconomic system that constitutes the farm is therefore important to understand the socioeconomic factors influencing agricultural productivity.

\footnotetext{
${ }^{6}$ Rain-fed paddy cultivation totally and even paddy under minor tanks to some extent is susceptible to adverse weather conditions. It is only paddy cultivated under major irrigation schemes escape adverse impact of bad weather.
} 
Figure 1: Labor Productivity as Earnings (Rs.) and Labor Share by Sector (2014)

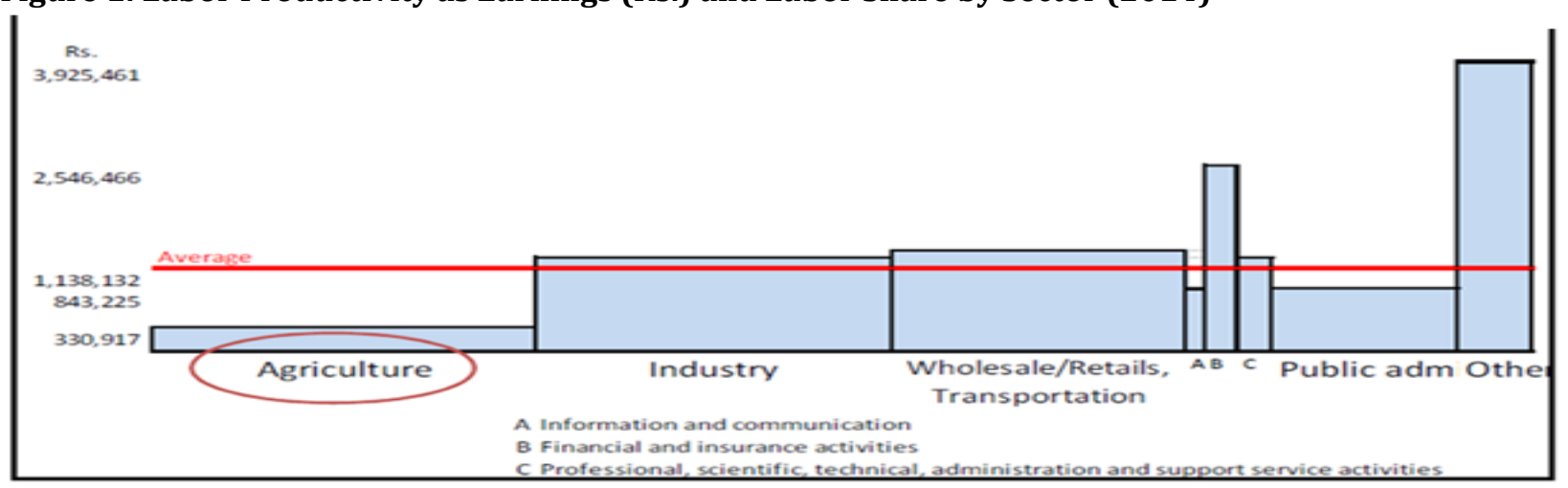

Source: Survey Findings, 2017/18.

Figure 2: Yield per Hectare of Selected Crops Comparison (Asia and World) 2013 (Kg/Ha)

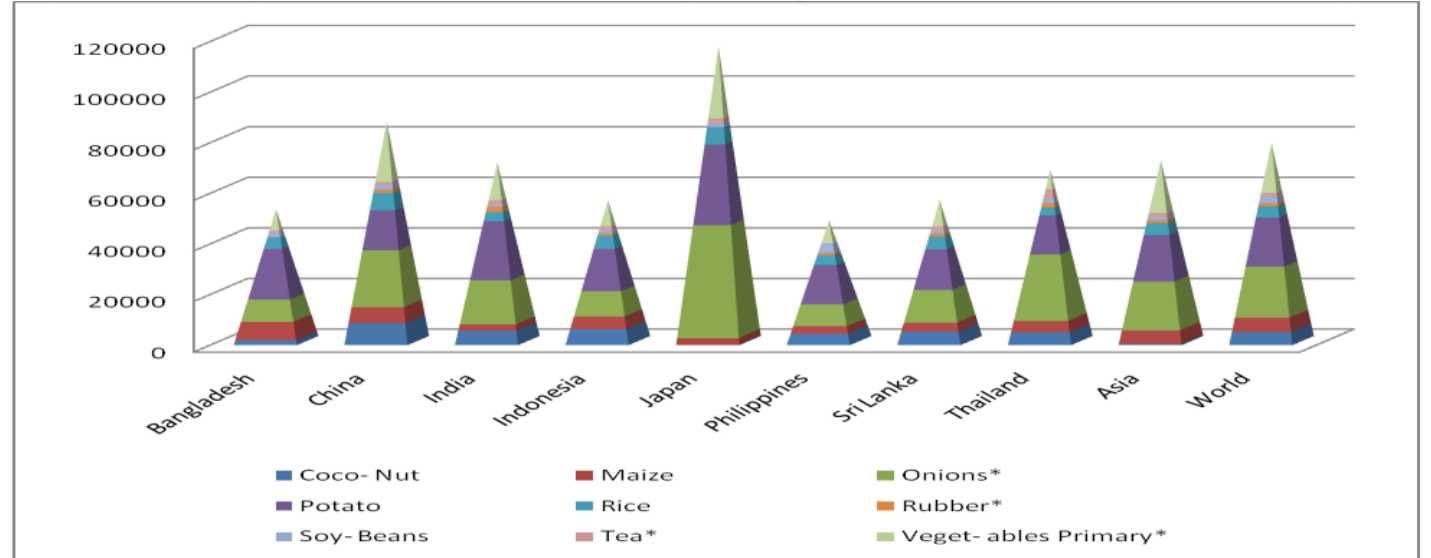

Source: Food and Agricultural Organization, http://faostat.fao.org/

*Data for 2012

Figure 3: Average Yield per Hectare of Paddy for Selected Years

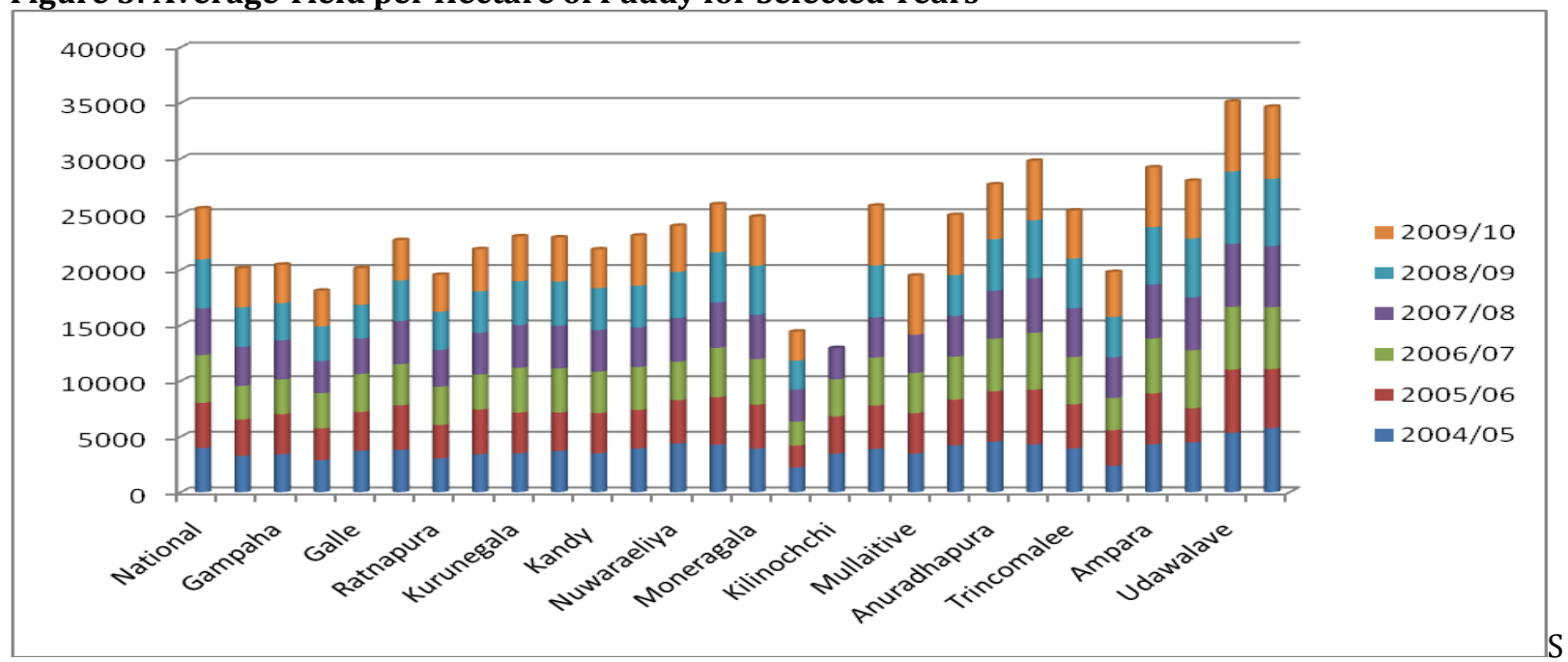

ource: (DCS, 2012).

Likewise, data on land productivity reveals that Sri Lanka's agricultural productivity is low compared to the major Asian producers and the world and Asian average productivity levels (Figure 2). It is also show that 
except for rice and the three plantation crops, namely, rubber, tea and coconut, the country's productivity measured in terms of yield per hectare is below Asian and world average. Yield levels for comparable crops are far below those for China and Japan. Yields of coconut, maize, potato, rice and soybeans are below Indonesia and yields of maize, onion, rubber, soybeans and tea are below those in Thailand. The country is ahead in productivity only in comparison to South Asia. This situation needs to be considered in the overall context that Sri Lanka's growth rate of agricultural productivity is very low in the region (Figure 2)

Socioeconomic Factors Influencing Agriculture Productivity in Sri Lanka: The findings by FGDs confirmed that socioeconomic system that constitutes agricultural operations in Sri Lanka can be analytically viewed as consisting of two core components, namely, the farm and the farmer. Whatever the size of the operation, these two units exists though their form and relationships may differ depending on the scale of the operation. The farm is not just a piece of land with crops but an organized set of relationships and operations centered around a piece of land set out for certain agricultural activity aiming at a certain production. Productivity becomes part of this as a determinant of the level of production. Farmer on the other hand is the operator who works within these set of relationships to achieve the objectives of the given farm activity, namely, production of a given crop. As part of achieving production objectives productivity also becomes part of farmer's operations. The farm as a system of operations and relationships can be viewed as follows.

Figure 4: Farm as a System of Operations

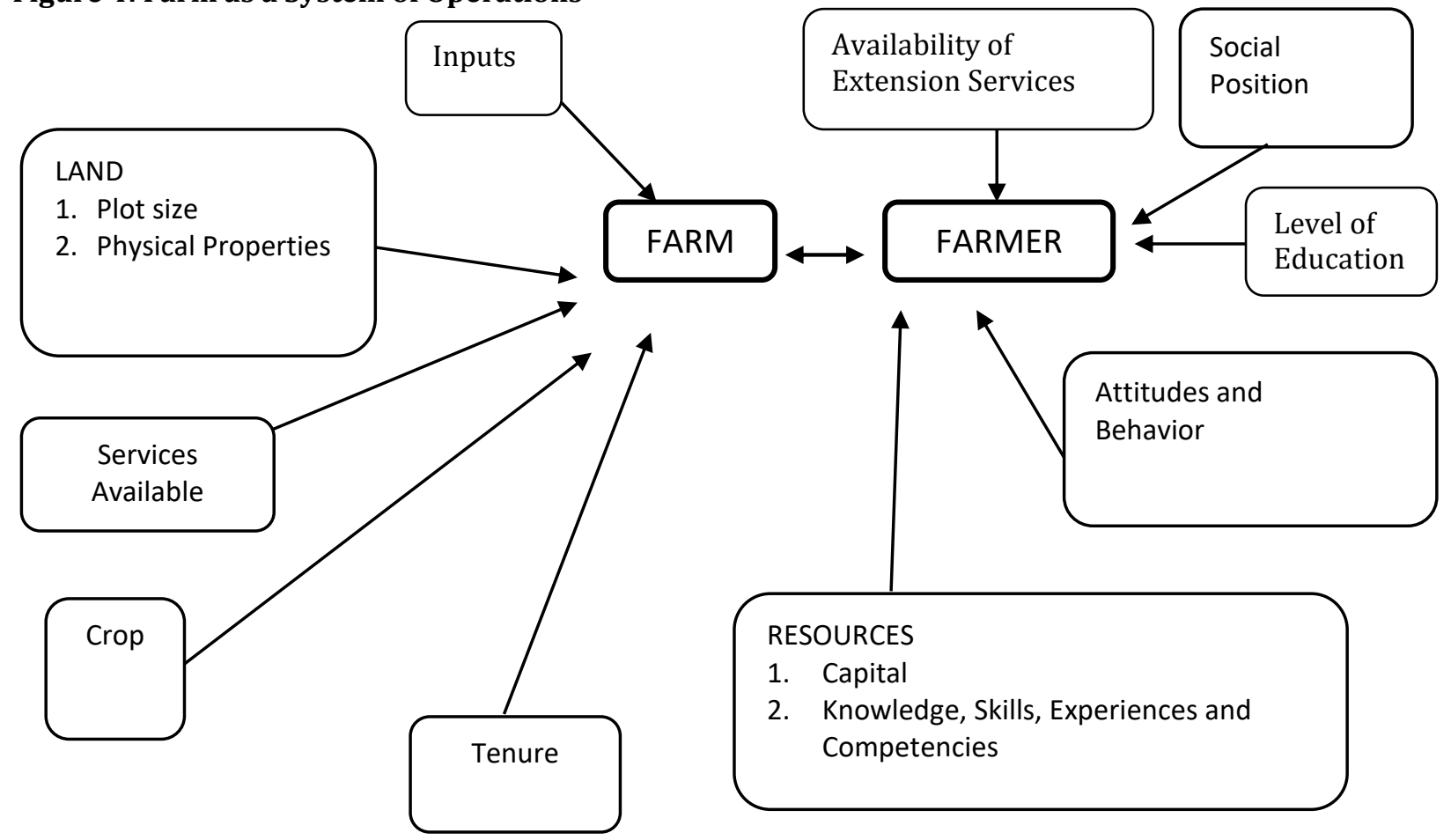

The above systemic view helps one to better understand the socioeconomic operations and relationship affecting the production process including productivity than viewing farm operations as separate activities. To help explain the farm production process and how the socioeconomic relationships in the above two components of the farm system affect agricultural productivity we propose to construct profiles of the two components. As stated earlier our concern is the non-plantation based farming system and the profiles are relevant to that context. This is consistent with findings of (Gamage \& Damayanthi, 2012), suggests that farmer behavior with regard crop choice, land tenure, production infrastructure and markets etc. are important.

The Farm in the Non-Plantation Sector: Non-plantation sector agriculture dominates agricultural production in Sri Lanka in terms of both the extent of cultivated land area and the number of 
farmers/operators. It is the principal producer of food crops, mainly for domestic consumption, and plays an increasingly important role. Commercial crop production in non-plantation sector targeting mainly a niche export market. These crops are officially known as Minor Export Crops which targeting both export and domestic markets. Provinces in Wet Zone Sri Lanka are dominant in cultivating these crops and discussions confirmed that these farmers are stable in income compare with those who cultivating in Dry Zone. The farm in the non-plantation agriculture sector is small in extent and on the basis of production levels and use can be divided into three types. In the first type are the farms that produce only for household consumption.

They are the smallest in extent of land with the farmers own these farms belong to the poorest segment in the community. The second type of farms is the ones that are able to produce a little excess over household needs, especially when the harvest is good, and the excess is sold in the market. However, these farms are not regular supplier to the market. The third category of farms produce primarily for the market and for the operators of these farms agriculture is an income generation activity not just a means of subsistence as for the farmers in the other two. A proportion of paddy farms in the Dry Zone belong and some specialized vegetable and filed crops farms, for example big onion and chili farms, are in the third category. One of the defining features of the farm in the non-plantation agriculture sector is land fragmentation and small plot size that are often not viable production units. The following table gives the distribution of paddy land by district and plot size (Figure 5).

\section{Figure 5: Land Fragmentation and Paddy Operations}

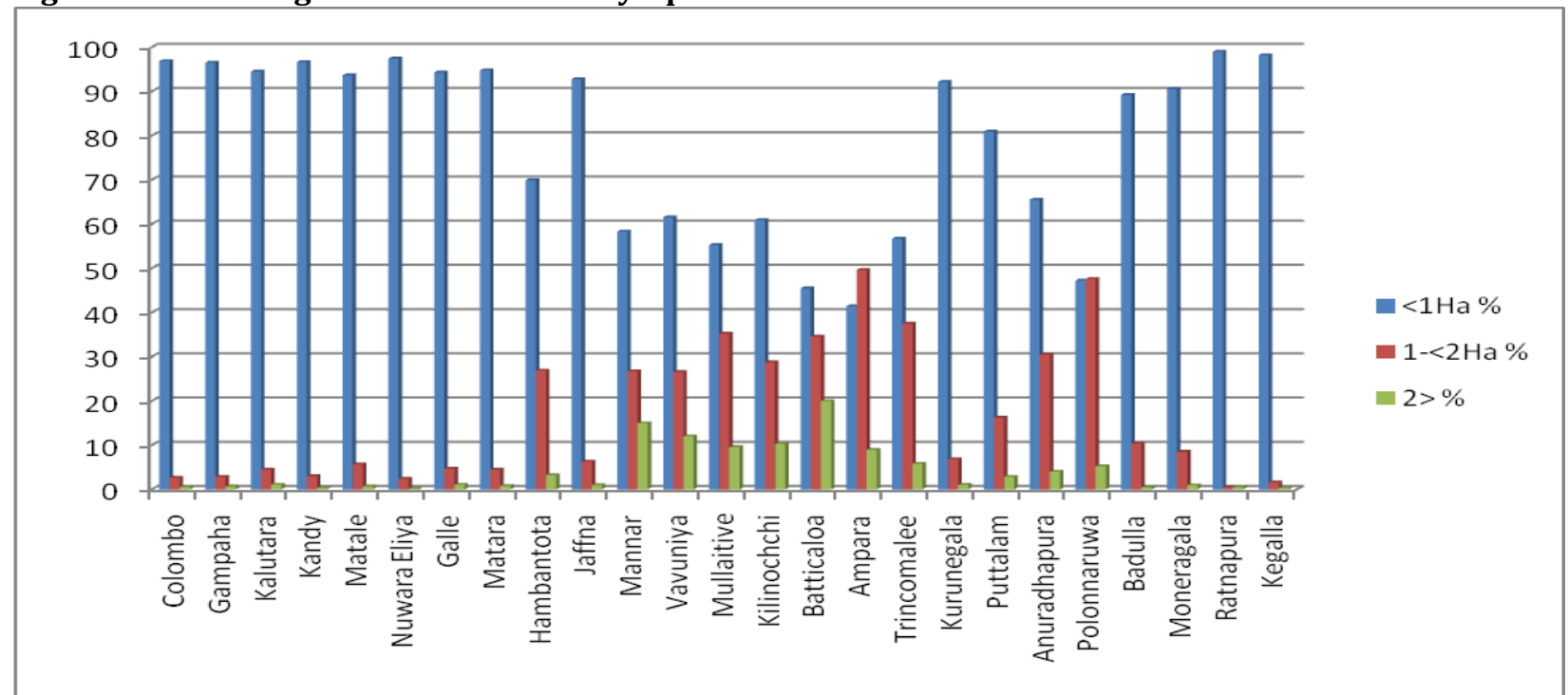

Source: (DCS, 2012)

The above table shows that except for the districts where there are new settlements established under either the old colony schemes or the Mahaweli Development Program in all other districts 90 per cent or more farms are less than 1 hectare in extent. The land plots of more than 2 hectares are on average less than 1 per cent of the plots, again except in the new settlement schemes. Small plot size makes cultivation economically non-viable discouraging enterprising farmers from taking up agriculture. As well, (Silva, 1999) confirmed that small plot size in Dry Zones of Sri Lanka makes paddy cultivation economically non-viable. Fragmentation leading to small plot size is inevitable in the agriculture sector when the economy fails to absorb the new addition to the household. Small plot sizes though theoretically not possible in the new settlement schemes in the country as there are legal restrictions sharing of land by children through informal arrangements lead to de facto division of land. In the other parts of the country and in purana (old) villages in the Dry Zone where there are no legal restrictions on agricultural plots being divided subdivisions creating small agricultural land is normal practice.

The problem of decreasing land size is an issue highlighted by the World Bank says that from 1982 to 1993 agricultural land plots less than one acre increased from 42 per cent to 62 per cent(World-Bank, 2009). 
According to this report there is a positive relationship between plot size and productivity in the districts for which data was analyzed (World-Bank, 2009). When size of the plot is getting smaller the land productivity is decreasing and this will lead to raise poverty. The second feature of the farm is land tenure which is of two types. In the Dry Zone settlement schemes, under both the Mahaweli Scheme and in the old Colony Settlements, there is a tenure type that prevents commercial transfer of land. Agricultural operators in the new settlements do not own their land as freehold and are prohibited from transferring their land to another party. This tenure type has been introduced to prevent land fragmentation but it has not succeeded in preventing land being either transferred or subdivided through informal deals. The second type of land tenure characterizing the farms is the one found in Dry Zone purana villages and in the villages in the rest of the country.

These farms are freehold land but often there is neither a legally partitioned plot nor a boundary marked by a formal survey. Boundaries are socially sanctioned boundaries for operational purposes. This latter form of tenure is a serious handicap in using land as collateral and also a problem affecting land transfer. Findings of (Silva, 1999) is consistent with these findings and highlighted that land tenure in the colonies especially does not help dynamic commercialization of farm operations. ${ }^{7}$ As a result of these situations, findings of FGSs showed that farm operators cultivated their land just for only consumption purposes and not for the market. This background did not help to generate a dynamic, risk bearing and innovative entrepreneurs for the country to lead other sectors in the economy as in western economies. The farm is also resource poor unit, particularly in relation to three main areas. Farm households are poor which is reflected in the higher levels of poverty in the rural sector. As stated earlier, average rural household's income is about $1 / 3$ less than that of an urban household. Poverty head count in the rural sector is twice that of the urban sector. Two other areas that reflect resource poverty is poor access, both physical reach due to poor transport facilities and road access and access to services.

The poor level of service access for agricultural services which has witnessed a marked deterioration in quality is a serious problem affecting the operations of farms in this sector. The other problem with regard to poor resources affecting the farm is low levels of education of farm operators (Figure 6) that makes farm short of personnel with skills and competence. This in consistent with the findings of (Jayasena, 1998), who claim that lack of skills and competencies is due to a combination of factors that includes better opportunities available in the other sectors that provide stable income, better work condition and social status that the farmers lack in the country. However, according to (Christiaensen, Demery, \& Kuhl, 2011), cross-country econometric evidence indicates that agriculture is significantly more effective in reducing poverty among the poorest of the poor. The farm is also highly dependent on two patrons, namely, the government and the trader collector. The government is the principal supplier of service to the farm that include extension service and welfare delivery (which is a must in the context of high poverty levels and frequent incidents of crop damages by draught) and also the market of produce.

The local trader/collector who has now effectively taken over the market from the government who once had the monopoly is expanding into other service areas, especially into the supply of inputs creating a vicious circle of credit based dependency ${ }^{8}$. Of these two patrons dependency on the government is perhaps inevitable and also is beneficial from a welfare point of view. It however has created a farmer with dependence mentality who expects the state come out and helps in everything. Lack of services, especially, government services resulted in farmers to rely on services. The weakened extension service mentioned earlier also has been indirectly responsible for this dependency between the farm operations and the trader. who confirmed that there are multiple pathways through which increases in agricultural productivity can reduce poverty, including real income changes, employment generation, rural non-farm multiplier effects, and food prices

\footnotetext{
${ }^{7}$ However, there are informal land transfers resulting in farm owners (Wanigaratne, 1995) in the new settlement schemes. These farmers are mainly from the local bureaucracy and white collar employees who interested in agriculture(Hettige, 1984; Moore, 1985).

${ }^{8}$ Farm inputs are supplied by the trader on the promise that the output is sold to him only. Price of the products bought and inputs sold and the credit and the interest rates are decided by the trader.
} 
effects. Further, it shows that barriers to technology adoption, initial asset endowments, and constraints to market access may all inhibit the ability of the poorest to participate in the gains from agricultural productivity growth.

Farmer in the Non-Plantation Crop Sector: Several of the features described under the farm setting are relevant to understand the farmer/farm operator in Sri Lanka's non-plantation sector. Through the FGDs in all provinces, it was found that the average farmer is a person operating at subsistence level. He is more often than not indebted and for that reason short of capital even for essential farm related expenses, both a reflection of widespread poverty in the sector. He is also below average educated, short of skills and competencies. Poor education and lack of skills and competencies coupled with tradition has also made him into a risk-averse individual, a quality that is not helpful in creating an enterprising farm operator. He is also often a part-time farm operator engaged in farming along with at least one other livelihood activity, often agriculture labor. All these negative features of the farmer are due to a combination of factors that include poverty, poor levels of education, attitudinal and behavioral traits and social position and beliefs. These findings are inconsistent with (Schneider, \& Gugerty, 2011).

The Figure 6 gives the level of education among paddy farmers which can be taken as an indicator of all small farmers/agriculture operators in the country. What is revealing in the data is very high percentage of people with no schooling at all. The percentage of people with no schooling among paddy farmers in sixteen districts is higher than the percentage of people with no schooling in the rural sector which 3.9 (HIES, 2012/13). Similarly the percentage of people with OL/AL qualifications is lower among agricultural producers in districts, except Colombo, Gampaha and Kalutara and Kandy, than the same percentage for the rural sector which is 26.8 per cent(HIES, 2012/13). Overall 80 per cent of the farmers have an education only up to grade 9 (only 5 years of education) making a vast majority of farmers are school dropouts by the country's standards. The farmer with a below average education is a result of several factors. First, the poor educational facilities available in farming communities do not offer either incentives or opportunities for children in the farm to complete their education.

Second the needs of agricultural households, for example the need to help as family labor, often disrupt education of children often making them to completely abandon education half way. Third the attraction of employment opportunities created in the industry and service sectors under the new economic policies. These finding are in consistent with (Laxman, Clement, \& Tisdell, 2000), who stated that even the few educated to abandon farm work for jobs that better paying and carry better social status leaving the poorly educated to remain in the farm. The result of all these is a poorly educated youth to engage in agriculture. The youth from farming communities taking up opportunities outside has several other percussions. It has resulted in a new class of youth who have a regular job with a better and stable income who are fortunate to work in a "prestigious environment" in the eyes of the farming youth. They are the envy of the village not only for the above but also because they do not labor in the field covered with mud. These employment opportunities with easy access to farms provide poverty stricken farmers an alternative source of employment without them completely taking away from the farm.

This allows farmers to continue cultivation work as well creating part time farmers. Survey finding by (Ranaweera, 1998; Weeraheva \& Abeygunawardhana, 1987) also support these findings who claim that while pat-time employment helps poor farmers to supplement their income it also results in a farmer who is not dedicated to agriculture. A farmer who is doubling up as an agricultural laborer for example has divided priorities and obligations it is the farm that gets neglected. Off farm employment for the majority of the poor farmers today, mainly because it pays better, has become the main livelihood activity. According to the finding of FGDs, it was revealed that Sri Lankan farmers on average derive 40 per cent of their income from off farm employment and there is large number of part-time farmers in the Dry Zone. These off farm opportunities were lead to reduce productivity both directly and indirectly in agriculture sector because poor farmers were attracted by easy gain in short-term by off farm employments. They have brought new styles, mannerism and attitudes in to the farm and these are influencing the youth even more to be out of their dirty work than even before. Lack of interest and young people leaving farm for number of reasons have resulted in higher levels of participation of elderly people in farming (Silva, 1999) further aggravating the situation. The 
farmer in this sector is typically a part-time farm operator which is primarily result of poverty in the farming household and of farm employment opportunities available with in and around farming communities.

Figure 6: Level of Education of Paddy Farmers by Districts

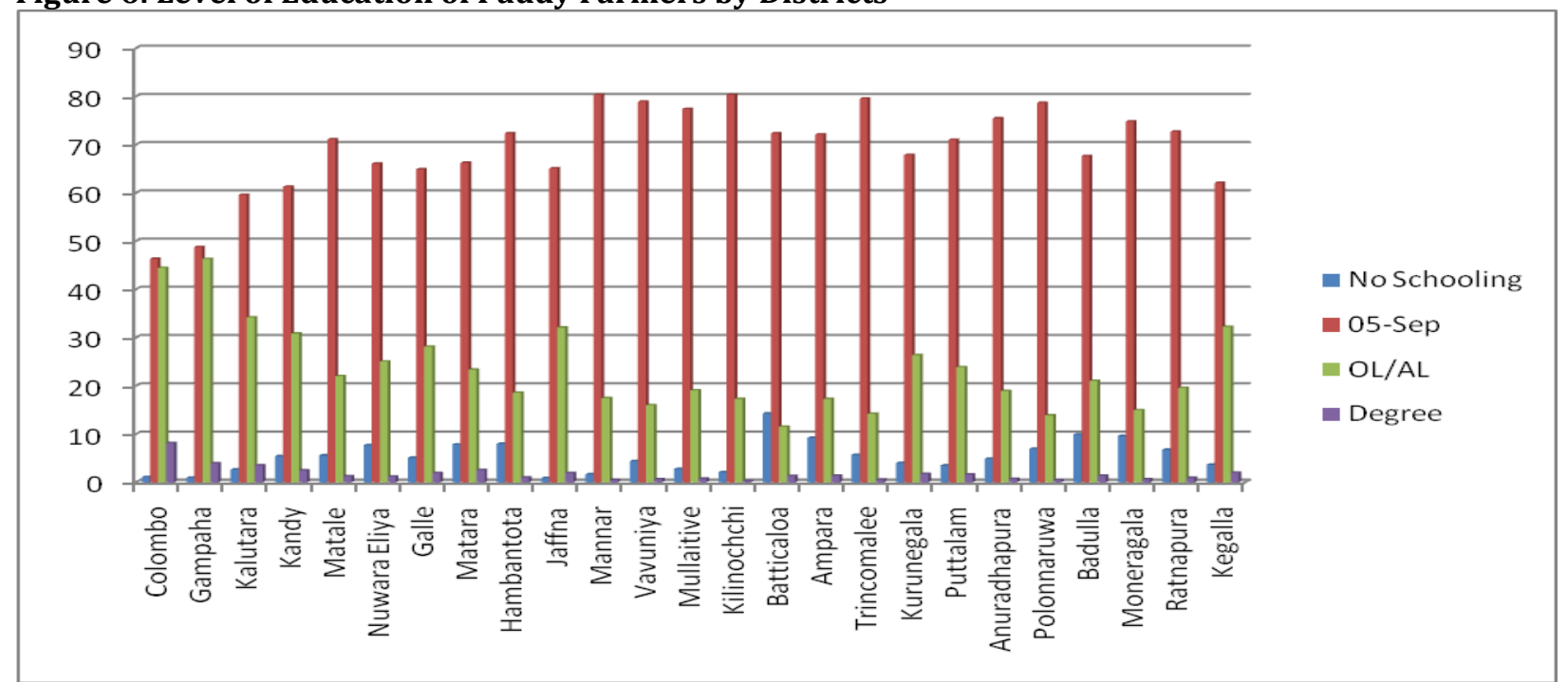

Source: (DCS, 2012).

This has created a group of young people with aspirations outside of the farm and waiting to be out of it at the first opportunity. The social push for non-farm employment comes not only from the peers who are employed outside but also from those who are their family members. The urban based employment not only has created a youth who is "modern" as against "backward farmer" it also has created a new class of families, the families of the youth employed outside. These families want their other children to follow the path of those who are urban employed. For example, in Central, Western and North Central Provinces young ladies who have factory work prefer their partner to be someone who is not a farmer, someone she can introduce to her associates/colleagues. Same with the sister who wants brother to match her new status. All this one way or other contribute to deprive farm of enterprising people.

\section{Conclusion and Recommendations}

Productivity in agriculture is determined by condition in both the natural factors and the socioeconomic factors. In examination of influence of socioeconomic factors analysts traditionally treat conditions that exist in the socioeconomic determinants in isolation. This factor based analysis of productivity though has its advantages also has limitations. Its main disadvantage is its failure to understand the interconnectivity and mutually reinforcing nature of socioeconomic issues. Size of the agricultural plots and tenure system has created many negative impacts on farmer and the productivity in the sector. Small plot size makes cultivation economically non-profitable discouraging innovative farmers from taking up agriculture. When size of the plot is getting smaller the land productivity is decreasing and this affecting to increase poverty. The existing form of tenure system is a serious handicap in using land as collateral and also a problem affecting land transfer. Land tenure in the Dry Zone colonies does not help dynamic commercialization of farm operations. Consequently, farm operators cultivated their land just for only consumption purposes and not for the market. This background does not help to generate a dynamic, risk bearing and enterprising farmers for the economy. The poor level of agricultural extension services were affected badly to deteriorate the quality of the operations and low productivity of farms.

The other problem with regard to poor resources affecting the farm is low levels of education of farm operators that makes farm short of personnel with skills and competence. These situations lead to low productivity and then prolongation of poverty. The farmer is also often a part-time operator engaged in farming along with at least one other livelihood activity, often agriculture labor. All these unconstructive 
features of the farmer are due to a combination of factors that include poor levels of education, attitudinal and behavioral traits and social position and beliefs affects low productivity and persistence of poverty. The result of all these is a less educated youth to engage in agriculture. All these one way or other contribute to deprive farm of enterprising people. Lack of interest and young people leaving agriculture for number of causes have resulted in higher levels of participation of elderly people in farming further infuriating the situation. The non-plantation farm is also highly dependent on two patrons, namely, the government and the trader. The government is the supplier of service to the farm that includes extension service and welfare delivery. The local trader who has gradually taken over the market from the government who once had the monopoly is expanding into other service areas, especially into the supply of inputs creating a vicious circle of credit based dependency. Of these two patrons dependency on the government has created a farmer with dependence mentality who expects the state come out and helps in everything.

The trader affecting to place in the poor farmer in to vicious cycle of poverty with dependency at all stages of farm operation. The study found that the conditions affecting productivity in the non-plantation agriculture sector is rooted in the two core components of the farming system, the farm and the farmer. They are two units in an interacting whole system which makes property of one a quality of another. Poverty which is a property of the farm makes a farmer who is short of capital for even essential farm related expenses. Factor based analysis of socioeconomic influence on productivity leads to neglecting essential connection of farm and farmer leading to incorrect understanding of the problem. Correct understanding of a problem is essential for proper development intervention and policy making for development. Therefore, issues connected with farm and farmer can be avoided only if we understand the complex interactions and dependencies in the farming system. The lack of attention to overall situation and lack of holistic approach to problems providing suitable solutions to individuals are constraints in agriculture development. Solving is the hall mark of policies and interventions in agriculture. Present focus is also on subsistence based model and the approach is piece meal. Equality based poverty alleviation may be politically safe and even beneficial but economically contradictory with liberal economic model.

\section{References}

Abeysekera, T. (2008). Performance of Sri Lanka's Agriculture Sector: Problems and Policy Issues. Paper presented at the Second Annual Research Forum of SAEA, 2008: Plenary Session. http://www.pgia.ac.lk/socs/saea/program2008/plenary/terance.pdf

Adamopoulos, T. \& Restuccia, D. (2014). The size distribution of farms and international productivity differences. American Economic Review, 104(6), 1667-1697.

CBSL. (2013). Annual Report 2013: Central Bank of Sri Lanka, Colombo.

CBSL. (2014). Annual Report 2014: Central Bank of Sri Lanka, Colombo.

CBSL. (2017). Annual Report 2017: Central Bank of Sri Lanka, Colombo.

Christiaensen, L., Demery, L. \& Kuhl, J. (2011). The (evolving) role of agriculture in poverty reduction-An empirical perspective. Journal of development economics, 96(2), 239-254.

Critical Factors Hampering Agricultural Productivity in Ethiopia:The Case of Northern Ethiopian Farmers (2007).

DCS. (2012). Agriculture Census 2012: Department of Census and Statistics, Colombo, Sri Lanka

DFID. (2004). Agriculture, growth and poverty Reduction: Agriculture and Natural Resource Team 2004, UK Department of International Development (DFID).

Dharmasiri, L. M. (2010). Measuring Agricultural Productivity Using the Average Productivity Index (API). Sri Lanka Journal of Advanced Social Studies, 1(2), 25-44.

Gamage, D. \& Damayanthi, M. K. N. (2012). Major Dimensions of Contemporary Small Holder Agriculture in Sri Lanka: HART, Colombo.

Gollin, D., Lagakos, D. \& Waugh, M. (2012). The agricultural productivity gap in developing countries. Quarterly Journal of Economics forthcoming.

Gunawardana, P. J. \& Somaratne, W. G. (2000). Non-Plantation Agricultural Economy of Sri Lanka: Trends, Issues and Prospects, Sri Lankan Journal of Agricultural Economics, 3(1), 15-45.

Hayami, Y. \& Ruttan, V. (1985). Agricultural Development: An International Perspective. Revised and expanded edition: Baltimore: Johns Hopkins University. 
Hettige, S. (1984). Power and Prestige: Emerging Patterns of Social Inequality in a Peasant Context: Colombo: Ministry of Higher Education.

HIES. (2012/13). Household Income and Expenditure Survey 2012/13: Department of Census and Statistics, Colombo, Sri Lanka

Jayasena, W. G. (1998). Rural Youth and Peasant Agriculture in Sri Lanka. In S. Hettige (Ed.), Globalization, Social Change and Youth: Centre for Anthropologic, Colombo.

Lagakos. \& Waugh, M. E. (2013). Selection, agriculture, and cross-country productivity differences. American Economic Review, 103(2), 948-980.

Laxman, W. D., Clement, A. \& Tisdell. (2000). "Introduction" in Laxman, Weligamage. D and Clements A. In Tisdell (Ed.), Sri Lanka's development since independence: socio-economic perspectives and analysis: New York: Nova Science Publishers.

Lewis, W. A. (1954). Economic Development with Unlimited Supplies of Labor: The Manchester School 22.

Mellor, J. W. (1986). Agriculture on the Road to Industrialization. In J. P. L. a. V. Kallab (Ed.), Development Strategies Reconsidered: New Brunswick, NJ: Overseas Development Council.

Moore, M. P. (1985). The State of Peasant Politics in Sri Lanka: London: Cambridge University Press.

Ranaweera, N. F. C. (1998). Fifty Years of Agriculture in Sri Lanka. In A. V. d. S. Indraratne (Ed.), Fifty Years of Lanka's Independence: A Socio-economic Review: Sri Lanka Institute of Social and Economic Studies, Colombo.

Schneider, K. \& Gugerty, M. K. (2011). Agricultural productivity and poverty reduction: Linkages and pathways. Libraries Test Journal, 1(1), 56-74.

Schultz, T. W. (1964). Transforming Traditional Agriculture: New Haven: Yale University Press.

Silva, K. T. (1999). No Future in Farming? The Potential Impact of Commercialization of Non-Plantation Agriculture on Rural Poverty in Sri Lanka: Kandy: Centre for International Community Health Studies and Colombo: Sri Lanka-German Technical Cooperation.

Szabo, P. (2003). Agricultural productivity indicators, Hungarian Statistical Review Hungarian Statistical Review 2014.

Wanigaratne, R. D. (1995). Informal Tenure Conditions in Irrigated Settlements in Sri Lanka: A Review of Empirical Research Evidence.

Weeraheva, J. P. \& Abeygunawardhana. (1987). Diminishing Profits of Paddy Production. Economic Review, Nov/Dec 1987

World-Bank. (2002). Wold Development Report. New York: World Bank.

World-Bank. (2009). Sri Lanka Agriculture Commercialization: Improving Farmers' Income in Poorest Regions: Poverty Reduction and Economic Management Sector Unit, The World Bank.

World-Bank. (2012). World Development Report. New York: World Bank.

World-Food-Programme. (2014). Sri Lanka - Rapid Drought Impact Assessment: Food Security and Livelihoods Affected by Erratic Weather, April 2014.

Xavier, I., Lin, L., Thirtle, C. \& Wiggins, S. (2001). Agricultural productivity growth and poverty alleviation. Development policy review, 19(4), 449-466. 